\title{
Working Capital Efficiency and Firm Value: Evidence form Pakistani Firms
}

\section{Shah $\mathrm{B}^{*}$ and Arif M}

Sindh Education Foundation, Shaheed Benazir Bhutto University, Pakistan

\begin{abstract}
Purpose: We examined the association between the efficiency of working capital and firm value for a sample of 49 firms registered on Karachi Stock Exchange for a period of 2004-2016. Additionally, the effect of financing constraints on this association is also examined.

Design: Linear and Fixed Effect regression analysis is used to capture the effect of working capital management on firm value. We follow the model which was developed by the Fama and French and use by Pinkowitz et al. and Wasiuzzaman.

Findings: We find that working capital efficiency is important for the firms as it affects the firm value and it improves firm efficiency by reducing the investment in working capital. Further, better management of working capital and firm value association is true for financially constrained firms. While, in case of unconstrained firms it the relationship insignificant.
\end{abstract}

Originality: To the best authors' knowledge, this is very first study on working capital and firm value in context of Pakistan. Hence this work adds valuable contribution in the scarce literature on working capital management and firm valuation relationship.

Keywords: Constrained; Firm value; Fixed effect regression; Karachi stock exchange; Unconstrained; Working capital

\section{Introduction}

The significance of management of working capital is not new in the literature of the finance field. The financial officers of corporate finance identify working capital management 1 as being important to their firm value 2 [1-3]. Liabilities and short-term asset management required a careful concentration since working capital management takes an important part in the determination of risk, profitability and liquidity as well as the ultimate objective of the firm value. Rehman and Nasr [4] stated that WCM is an important issue for every firm. It directly influences on profitability and liquidity of companies. Working Capital Management holds day to day transactions of financial managers of the firms. Charitou et al. [5] suggest that companies' resources used efficiently, increases the profitability of the company which also cause to reduce the default risk and increases the value of the company. In the same line, Afza and Nazir [6] also believe that implementing bad management policies for WCM negatively influence the profitability. Lots of research carried out on the issue of WCM and the profitability in different countries, some of them are Lazaridis and Tryfonidis [7], Rehman and Nasr [4], Falope and Ajilore [8], Mathuva [9], Mansoori and Muhammad [10], these all studies analyzed the effects of WCM on the profitability of the firms. Most recent studies such as Ponsian et al. Adebowale et al. Ismail, Singh and Kumar, the results of these meta-studies proved that working capital is negatively associated with the profitability, hence these all previous studies is not sufficient to evaluate the working capital effects because these all studies consider the effects of WCM on profitability, but the effects of working capital is still needed to consider examining other aspects such as dividend policies, shareholder wealth, level of taxes and the firm value.

As stated by available literature, a small number of studies have been done in the area of working capital management in Pakistan and with the very best knowledge of the author, there is no research done describe the effects of working capital and the firm value especially in Pakistan. Additionally, no research has found which have used Fama and French model to evaluate the firm value with working capital context? For that reason, the researchers likely to examine the significance of the working capital in especially, industrial parts of the economy of Pakistan and the impact as well as association with firm value. Although the studies enhance the WCM make sure the utilization of current liabilities and current assets in Pakistani firms to attain the fundamental objective of the creation of value, this will be used in fill out the gap.

Furthermore, it will also helpful for designing the policies for the management of optimal level of working capital to make the best use of the firm value for maintaining the sustainability of their growth of the business. This study will increase the understanding of organization that how to handle risk, liquidity, and profitability apart from the theoretical explanation, in addition, the methods in which working capital helpful to creating the firm valuation for the feasible operations.

Remaining the structure of this paper is as follows: the next part presents the previous studies on the measuring the association of working capital and firm value. In addition, the possible influence of financing constraints on this association. The next section presents the methodology and hypothesis construction on the basis of previous studies. Section 4 presents the findings of our study. Discussion on findings is presented in section 5 and in section 6 we conclude our research work.

*Corresponding author: Bab Shah, Sindh Education Foundation, Shaheed Benazir Bhutto University, Pakistan, Tel: +923368934865; E-mail: babshah75@gmail.com

Received January 27, 2018; Accepted February 20, 2018; Published February 28, 2018

Citation: Shah B, Arif M (2018) Working Capital Efficiency and Firm Value: Evidence form Pakistani Firms. J Bus Fin Aff 7: 320. doi: 10.4172/2167-0234.1000320

Copyright: @ 2018 Shah B, et al. This is an open-access article distributed under the terms of the Creative Commons Attribution License, which permits unrestricted use, distribution, and reproduction in any medium, provided the original author and source are credited. 


\section{Literature Review}

In this section, we discuss on previous studies of the association between the working capital and the firm value. The importance of the working capital management is not new in the corporate finance literature review.

\section{Concept of working capital}

The current assets minus from the current liabilities the remainder is called the working capital [11]. The working capital term means an investment of a firm in short-term assets like cash, inventories, account receivables and short securities [12]. Working capital is interval among the expenses of purchases of the material and collections made for the sale of the final products [13]. Further, Pandey [14] management of working capital describes as managing all the working capital components such as cash, account receivables, and debtors, etc. The significance of function of management of working capital is essential to firms because of it involves investment, time as well as the growth prospects of the firm. A number studies were carried out on the association of working capital management with the profitability of the firms. For understanding this concept of working capital, it is necessary to understand its two concepts.

Gross working capital: According to this concept, gross working capital means an outlay of firm's current assets. Current assets describe as those assets that can be easily transformed into the cash or near cash in a year. According to Paramasivan and Subramanian [15] in hand total cash, cash equivalent that a business used to run its daily operations is called gross working capital. Cash equivalent includes short-term investments, inventories, account receivables, marketable securities which liquidated during a year. The total current liabilities are not minus from total current assets. This concept views the working capital and sum of the current assets as two similar terms. This is also called circulating capital or current capital. Further, another aspect of gross working capital is that it used to arrange the finances for funding the current assets. So, the financial executives are supposed to have knowledge about the source and origins, of funds for working capital as well as other outlay where the redundant source may be, for the time being, are invested.

Net working capital: Net working capital defines as current assets minus from current liabilities. The current liabilities are obligations which paid during or within a year and involves account payable, loan payable, notes payable, outstanding expense and bill payable. The mathematical expression is as follows:

\section{Net working capital=Current assets-Current liabilities}

Net working capital may be positive or the negative. Brigham and Houston [16], according to them (NWC positive and negative) both have equal significance for the management. Thus, positive working capital focus on the optimal investments and funding the current assets, while negative working capital indicates the position of liquidity and proposed that how much amount of working capital required to finance from the permanent resources of the funds. It is supposed that current assets are in surplus as compared to current liabilities as it provides them an edge for fulfilling the firm's short-term debt within an operating cycle of the firm operations. Net working capital also comprises the question regarding the well-organized combination of the short-term and the long-term resources for financing the current assets.

\section{Working capital and profitability}

Most of the studies analyzed relationship and impact of management of working capital and profitability in different countries and used with different data analysis procedures such as Eljelly [17], Charitou et al. [5], Gill et al. [18], Mathuva [9], Viba et al. [19], Alipour [20], Al-Debi'e [21], Rahman [22], Usama [23], Akbar and Arani [24], Onwumere et al. [25], Pouraghajan and Emamgholipourarchi [26], Ali and Ali [27], Sarbapriya Ray [28], Uremadu et al. [29], Ding and Guariglia [30], Zubair and Muhammad [31], Oladipupo and Okafor [32] all these arrived at the similar conclusion that profitability and different measures of management of working capital had a negative relationship. In contrast with these studies, Lazaridis and Tryfonidis [7], Reddy [33], Ngwenya [34], Barine [35], Owolabi and Alu [36], Mansoori and Muhammad [10], Mousavi and Jari [37], Okwo et al. [38], Ghaziani and Zadeh [39], Mehra [40], Hamid and Waqar [41], Alavinasab and Davoudi [42] found that working capital is positively related to the profitability. Concluding the results of these studies, some authors' proofs that significantly positive association exist between WCM and the profitability, on the other hand, some authors disagree about this relationship. These results indicate that if firms managed their working capital efficiently it may be lead to the profitability. However, this area is still open to the future research. However, previous studies on profitability are still insufficient as "these financial numbers may have little to do with what is good or bad for the firm" plus the value of firms' goal is to optimize the profit and safety. Therefore, it is also essential to identify the effects and to know the association between the WC and the firm value. Unfortunately, there is still a lack of studies focuses on the valuation of WC but there is a significant and rising number of works analyses the management of cash and the firm value.

\section{Working capital and firm value}

Most of the studies construct the relationship between the cash holdings and the firm value such as by Dittmar and Mahrt-Smith [43], Pinkowitz et al. [2], Kalcheva and Lins [44] found significant positive results that Shareholder protection increases, the value of cash holdings are also increasing at the country level. Luo and Hachiya [45], Dittmar and Marht-Smith [43] and Lee and Lee [46] they found governance/ agency problem is a key factor of negative associated with the value of a firm and its cash holdings, this negativity more seen in the firms with, (I) the lower number of directors from outside, (II) large number of boards and (III) the higher supposed managerial buffer. The firms which hold cash in excess, firm value is discounted by the investors when the mechanism of corporate governance imposed not strong control to hold on managerial uses of the excess cash. Faulkender and Wang analyzed the marginal cash value and found that decline in cash value is due to holding too much cash, better access to capital markets, higher leverage, and higher for those firms distributes cash through dividends relatively to repurchases. Harford [47], Opler et al. [48] study a crosssectional difference in the degree of cash holdings, they had found that companies with more high risky cashflows, not the better accessibility of the capital markets, and stronger growth opportunities to hold a greater amount of cash balances. However, for the first time using Faulkender and Wang model by Kieschnick et al. [49], study the association of working capital management, firm value and agency costs that how it affects this association and find the evidence that investment of an additional dollar in the net operating capital, these investments reached some level may decrease the firm value and in addition, exclusion of the agency costs is important in previous models of in fluence of working capital management on the value of the company. Luo [50] analyzed the efficiency of the working capital affects firm value and the profitability. The study finds that improvement in efficiency of the working capital leads to the increases in the future earnings. The decrease in the cash conversion is the increases in firm value. Further, the firm with the 
limited the debt capacity may be significantly increasing the firm value. Mohamad and Saad [51] examined the influence of working capital management to profitability and firms' market valuation. The results of their study reveal a considerable negative relation exists between the market value of a firm and profitability. Further, they highlighted the significance of requirement of managing the working capital efficiently to ensure the betterment in the market value of the firm and profitability. Parvaneh and Chashmi [52] analyses the impact of financing methods and the working capital management of the value of listed firms at Tehran Stock Exchange. Find that working capital is significantly related to firm value. Wasiuzzaman [3] examined the association between the efficiency of working capital and firm value, moreover, examined effects of the financial constraint on this relationship. Her study finds that improvement in efficiency of working capital through making the decline in the investment of working capital leads to the greater firm value. Further found that this relationship is affected by the financing constraint faced by the firm.

\section{The effects of financial constraint and unconstrained on association of working capital and firm value}

Almeida et al. [53] examined the cash flow sensitivity and influence of financial constraints on the firm's policies and realized that the constrained firms demonstrate significant positive cash flow sensitivities for the constrained firms whereas, unconstrained firms do not. Moyen [54] analysis influence of financing constraints and unconstrained and have on sensitivities of the investment of firms in their cash flow. Found that constrained firm exhibits higher cash flow sensitivity as unconstrained does not. Faulkender and Wang too, analyzed the hypothesis that cash holdings' extra dollar is more important to shareholders in firms which are financially constrained, examined through different proxies for classified dividend payout ratio, commercial paper rating, firm size and long-term bond rating. They find a negative median for financial constraint and a positive median for the unconstrained firms under all four measures. They recommend that constrained firm's face more difficulties in accessing the capital; firms have to lower their cash holding as compared to the unconstrained firms. In addition, constrained have greater cash holding than the unconstrained firms. Plus shareholders invest more of that cash of the constrained firms rather than on the unconstrained firms for the reason that of the costs related to the cash holdings, including the agency costs. de Almedia and William [55] examined impacts of financial leverage on the relation of working capital management and the company value as well as how this relationship is affected by financial constraint. In addition, they also analyzed the relationship between working capital and the company value. They find evidence an extra dollar investment in the working capital is not more significant, on average, rather than an extra dollar invested in the cash and on average, firm value declines if increasing the amount of the working capital at the beginning of the accounting year. Nakamura and Palombini examined the determinants of working capital and proposed the results that amount of debt, the growth rate can influence the working capital of the firms as well as find working capital is significantly negatively related to company size. Denis and Sibilkov [56] also suggest that level of investment is higher for the constrained firms as well as hold more cash and are increasing the value response to the costly the external financing than unconstrained firms.

Further, their findings contrary Kieschnick et al. [57] and Chiou et al. [58] studies found the size of the firm positive correlated with the working capital in efficiencies. Wasiuzzaman [3] also found that efficiency of working capital, notably increases the firm value of the financial constraint firm but it is found that for financially unconstrained firms, the efficiency of working capital is not significant. Baños-Caballero et al. analysis the relationship between the investment in the working capital and the firm value, their results signified that, although a concave relation between the investment in the working capital and the performance of firm always holds, firms with the best possible level of the working capital is finding lesser for the financially constrained than unconstrained firms. Kieschnick et al. analysis the effects working capital management on the wealth of shareholders and find that cash is much valued than working capital. In addition, their analysis exhibits the influence of financing constraints on working capital valuation. Fazzari et al. proposed that the investment of the firm may rely on the financial aspect, such as capital market access, financing cost and accessibility of the internal finance. Fazzari and Petersen proposed that the investment in the working capital is possibly more unstable to the financially constrained as compare to the investment in the fixed capital.

All these previous studies on the value of the working capital verified two things. First, the significant influence of working capital on the value of the firm and second, financing constraints have significantly influenced this relation. On the other hand, these studies are not sufficient and more empirical evidence is required for support of all these results, especially, in the context of Pakistan. In this study, we intend to measure the association between working capital and firm value of listed firms of Pakistan, an emerging market and find whether these all findings all validate for the firms of Pakistan or otherwise. On the basis of these studies conducted in the different countries, we have developed our methodology used Fama and French [1], Pinkowitz et al. [2], Wasiuzzaman [3] model as the baseline for our study.

\section{Objective and Hypothesis Formulation}

We used standard free cash flow model of valuation which shows an investment of the firms in their net operating capital. Previous studies proposed that association between working capital and firm value is complicated. Kieschnick et al. [49] and Luo [50] and Wasiuzzaman [3] discussed in their studies that a negative association is generally supposed since decreasing in working capital investments means greater the profitability and therefore, have to higher the firm value. To see this, we used following valuation expression is given by Brigham and Daves [16] and Eharhardt and Brigham for the firm valuation:

$$
\mathrm{V}_{\text {firm }}=\sum_{\mathrm{t}-1}^{\infty} \frac{\mathrm{FCF}_{\mathrm{t}}}{(1+\mathrm{WACC})^{\mathrm{T}}}
$$

Where $\mathrm{FCF}_{\mathrm{t}}=\mathrm{NOPAT}_{\mathrm{t}}-\mathrm{NOWC}_{\mathrm{t}}-\Delta$ Fixed Assets. $\mathrm{NOWC}_{\mathrm{t}}$ is the change in NWC at time $t$ or the investment in working capital at time $t$, Fixed Assets $t$ is the change in the value of the firm's fixed assets or its investment the long-term assets, $\mathrm{FCF}_{\mathrm{t}}$ is the free cash flow at time $t$ and $\operatorname{NOPAT}_{t}$ is the net operating profits after taxes at time t. From abovementioned expression it is understood that make an investment in the NWC is an essential determinant of the value of the firm, but from it is not understandable that what is the association is due to the investment in the net working capital is similar to the investment makes in longterm assets in that decrease FCF at the same time as affecting the future cash flow. Kieschnick et al. [49] argue that in fact, this association is more complex the reason behind this is the influence of the $\mathrm{WC}$ on the future sales. For example, Brigham and Houston [16] explain that too much stock of inventory is not to be good for today as it will diminish the future cash flow today, but at the as time it helps in any complicated situation seen due to stock-outs which may reasons affect profitability and goodwill and makes troubles in future production. 
Similarly, Salek argued that the strict credit policy may decrease receivables and the bad debt losses for today, however, it also decreases the future sales. So, the first object of our study, to find out the association between the working capital and firm value of the firms. Kieschnick et al. [49] point out that each component of working capital has affected future sales and the firm value, especially linked to credit policy and inventory policy of the firm, affecting the firm value; these are a few reasons behind a complicated association. Hence, to test the first objective of our study, we formulate the first hypothesis is:

- $\mathrm{H}_{1 \mathrm{a}}$ - There is a positive association of WC with firm value.

- $\mathrm{H}_{1 \mathrm{~b}}$ - There is a no association of WC with firm value.

Furthermore, larger firms have better access to the capital as compared to the smaller firms. Evidence found in the studies of Almeida et al. [53] and Pinkowitz et al. [2] that cash holding is more important for the constrained firms than for the unconstrained firms and a source for the increases the value, respectively.

Denis and Sibilkov [56] illustrate that the cash holdings are linked to the high investment for the constrained firms and this is linked to a higher value than that of unconstrained firms and also added that greater the cash holdings are the reasons for increasing the value to the financing fractions. The second objective of this study is to understand that either working capital is influence the firm value in a different way in the constrained firms than in the unconstrained firms. Kieschnick et al. verified that the NWC value is then influenced by the financial constraints. There are different proxies for sorting the firms into financing constrained and unconstrained, however, it is seen that there is no general agreement on the proxies that which one is the best measure for the financial constraint. In our study, we used size as a proxy of categorizing the firms into a financially constrained and unconstrained. On the basis of these previous studies, we develop our second objective of our study; determine the influence of the working capital investment on the valuation of financial constrained and unconstrained firms. Therefore, it is expected that decreasing the investment in working capital may lead to higher value for the financially constrained firms as liken for the unconstrained firms:

- $\mathrm{H}_{2 \mathrm{a}}$ - The negative influence of WC on firm value is greater for the financially constrained firms.

- $\mathrm{H}_{2 \mathrm{~b}}$ - The negative influence of WC on firm value is greater for the financially unconstrained firms.

\section{Model Specification and Variables}

For the analysis of this study, we used a valuation model of Fama and French's [1], which associated with characteristics of firm value, utilizes a set of different variables consist of investments, R\&D expenditure and earnings to the proxy for the net cash flows. This model modifies by Pinkowitz et al. [2] to study the valuation of cash. In Equation (1) of the free cash flow comprise all characteristics determine by Fama and French in addition to the NWC. Thus, we are making further changes in the model according to the need of this study to include the NWC as a result that finds out the importance and efficiency of net working capital concerning with firm value of the firms. To test the two hypotheses, the mathematical expression of the model is as follows:

Value $_{i t}=\alpha_{0}+\beta_{1}$ Earnings $\beta_{2} \Delta$ Earnings $_{i t}+\beta_{3} \Delta$ Earnings $_{i t+1}+\beta_{4}$ Net Asset $_{i t}$ $+\beta_{5} \Delta$ NetAssets $_{i t+1}+\beta_{6}$ Interest $_{i t}+\beta$, Interest ${ }_{i t}+\beta_{8} \Delta$ Interest $_{i t+1}+\beta_{9} R n D_{i t}+\beta_{10} \Delta$ $R n D_{i t}+\beta_{11} \Delta R n D_{i t+1}+\beta_{12}$ Dividend $_{i t}+\beta_{13} \Delta$ Dividend $_{i t}+\beta_{14} \Delta$ Dividend $_{i t+1}+\beta_{15}$ Cash $_{i t}+\beta_{16} N W C_{i t}+\beta_{1}, \Delta$ Value $_{i t+1}+e_{i t}$
Where $\mathrm{X}_{\mathrm{it}}$ is the level of the variable $\mathrm{X}$ in the year ${ }_{\mathrm{t}}$;

$\Delta X_{i t}$ shows change in $\mathrm{X}$ over year ${ }_{\mathrm{t}-1}$ to the year ${ }_{\mathrm{t}}$;

$\Delta X_{i t+1}$ shows change for $\mathrm{X}$ over the year ${ }_{\mathrm{t}+1}$;

$e$ is the error term.

Whereas, Value represents the firm value (dependent variable) calculated as the firm's total market value. It is computed as the common stock price of firm time share outstanding at the end of the year (or its capitalization) plus preferred stock (taken, if available, par value, liquidity value or redemption value) plus total book liabilities minus investment credit, deferred taxes, if available. We used common stock price shares outstanding plus total liabilities minus deferred taxes.

The independent variable of this study, we used to measure Earnings as before extraordinary items plus interest expenses as in the scenario of Pakistani firms remaining two items investment tax credit and income statement deferred tax credit is not found in financial statements. Net Asset is computed as total assets minus marketable securities and cash and minus the portion of the net working capital (i.e., Inventories plus account receivable). As a measure of leverage Fama and French used interest expenses, according to them it expresses the leverage policy of the firm, so we used interest expense (interest) in our variable set. Fama and French [1] and Pinkowitz et al. [2], research and development expenditure include in their variable set because it is necessary for the USA. In Pakistani firm's cases, it is not compulsory, but it is included in the model for the robustness as shown in Pinkowitz et al. [2] and Wasiuzzaman [3]. $\mathrm{R} \& \mathrm{D}$ expenditure $(\mathrm{RnD})$ is computed as the $\mathrm{R} \& \mathrm{D}$ expenses of the firm (assumed 0 if missing) for all firms analyzed in this study. Hence this variable, in this study expected insignificant. We measure dividend policy (dividend) as a common dividend paid out by firms, similar to the study of Pinkowitz et al. [2]. We measure cash holdings using cash and marketable securities to the net assets compute as total net assets minus from marketable securities and cash, similar to Fama and French [1], Opler et al. [48]. All the variable set on the book value of the assets in the year $t$ to solve the problem of the heteroscedasticity.

Next, for the examining the effects of financing constraints on net working capital valuation; we divided firms into two groups on the basis of size. There are various proxies' presents by Fama and French [1] longterm board rating, dividend policy, size and commercial paper rating. But, again in Pakistani firm's cases, it is difficult to find these proxies due to the not active participation of Pakistani firms in issuing these two securities. For the proper categorizing firm's dividend payout is also not much effective as the proxy of the financing constraints. Therefore, size has its own limitation as a measure for the financing constraint, for this study it is considered most appropriate for classification. First, we compute the size of all firms included those which are excluded from the sample as calculate median for the entire population firms. Size calculates by the means of natural logarithm of total assets, and then the median is computed for every year over the period of 2004-2016. Then, the firms with an under the value of median consider "constrained" and with a higher value than median place "unconstrained" group. Previous studies mostly used decile for categorizing firms but we used the median because of sample size limitation. Generally, it is seen that some of the firms are found under the category of constrained but also found in another year under the unconstrained category. It is expected from the studies of Fazzari and Petersen, Faulkender and Wang and Denis and Sibilkov [56] gives evidence, smaller firms tend to have higher financial constraints and therefore these firms a higher value will be allocated to NWC investment. 


\section{Data and Summary Statistics}

In order to test the hypothesis formulated in this paper, we used the model developed by Fama and French [1]. The study used data from Karachi Stock Exchange (KSE) for the period of thirteen years from 2004 to 2016. Starting with an initial sample of 194 firms and data collected from the website of KSE and Opendoor.pk database, all firms in financial services were excluded from the sample as these firms working capital is different in nature as compared to financial firms. Then, firms for which not all required data variables were available were eliminated. After the elimination of all these firms, the final sample of 49 firms of twenty-three different industrial sectors of the Pakistani economy. Classification of the data on the basis of financial constrained, 33 firms were a financial constrained group and 13 were from unconstrained. This paper is used based on quantitative secondary data in nature using annual published reports of firms mentioned in Table 1. Summary Statistics.

Table 1 reports the summary of descriptive statistics for each variable used in this study. From Table 1, it is clear that the total number of observation is 490. Moreover, there are not many discrepancies between mean and median, but it seems between the minimum and maximum values of the variables. Compare with previous US studies [59], French firms, Brazilian firms [53], Malaysian firms, some differences can be highlighted. The average level of Cash holding $\left(\right.$ cash $\left._{t}\right)$ is $(0.043)$; this value is much higher compared to the average level of NWC (0.168), this finding found to be consistent with previous studies. The maximum value for cash holding is (0.573) and for NWC (1.375). While the average level of dividend is higher (0.050), than it is in Malaysia (0.013), Brazil (0.0094) and then in French (0.001) but the minimum and maximum values $(0,1.105$, respectively) is in line with the result of Malaysia $(0,1.106$, respectively). Further, on average, investment in net assets (NetAsset) is much higher in Pakistan (0.672), is a little bit closer to one of Brazilian firms (0.3976) but very far from that Malaysian and French firms (0.013 and 0.038). Again, change in earning (Earning ${ }_{t}$ ) is much higher in Pakistan (0.098) than that of previous studies Malaysian firms (0.036777), Brazilian firms (0.0694) and French firms (-0.005) are negative in Us firms (0.011).

Table 2 reports the calculation summary of descriptive statistics significance in the difference of the mean values for each variable for the constrained and unconstrained firms.

The variables, except Earning, Earning $_{t+1}$, Dividend, and Dividend $d_{t+1}$; the mean is higher for constrained firms. Constrained firms have a higher level of $\mathrm{NWC}_{t}(0.155933379$ compared to 0.195327154$)$. Constrained firms are found to be higher Earning (0.119142837 as compared 0.055248985) despite the financing constraints faced. On the other hand, Net Assets ${ }_{t}$ and Net Asset ${ }_{t+1}$ are found to be higher (59.19699461 as compared to 0.034537306 and 0.019338863 against 0.015381063 , respectively). Net Assets $s_{t+1}$ variable shows a significant difference in the mean at the level of 10 percent. Moreover, interestingly found, the constrained firms pay higher dividends on average while difference is insignificant for payout. Also cash holding, the mean is higher for the constrained firms $(0.048885697)$ as compared to the unconstrained firms (0.032138709), these statistics results are similar with the findings of Faulkender and Wang. Since access to the external funds is a problem for the constrained firms, mostly they rely on internal funds and so hold the higher level of cash balances.

\section{Analysis of Result}

In this section, we analyze the result of regressions for the panel of the firms that try to analyze the effects of working capital on firm value for the period of 2004 to 2016 . The data comprises natures of time series because the study used thirteen year time period and crosssectional in nature because it has 49 firms. Therefore, the researchers used OLS regression technique for analysis with dummy variables for measuring the effects of WC and firm value. First, we analyze the results of different regression shown in Tables 3-5 for the entire sample of the firms, in order to capture the effects of working capital on firm value. Next, we, divide the sample into two groups financial constrained and unconstrained and sought to separately analysis the effects of financially constrained on the relationship of working capital and firm value and the result of regression shown in Tables 6 and 7.

\section{Effects of working capital on firm value}

Panel (I) of Table 3 presents the result of linear regression analysis for entire sample to seek the effects of WCM on firm value for the period of 2004-2016. NWC is highly significant $(p=0.006)$ at the level of 1 percent and negatively effects the firm value. Earnings and $\Delta$ Earnings both are found to be highly significant $(\mathrm{p}=0.000)$ at the level of 1 percent and positively related. $\Delta$ Earnings $_{t+1}$ are found to be insignificant. Interest is $_{t}$ found to be highly significant $(\mathrm{p}=0.001)$ at the level of 1 percent and has positively related. $\Delta$ Interest $_{t+1}$ are found to be significant $(\mathrm{p}=0.083)$ at the level of 10 percent and negatively related to the firms and $\Delta$ Interest $_{t}$ is found negatively insignificant. Dividend $d_{t}$ is significant $(p=0.020)$ at the level of 5 percent and positively affect the firm value. $\Delta$ Dividend and $\Delta$ Dividend $_{t+1}$ are found to be negatively insignificant. $\Delta$ Net Assets ${ }_{t}$ $\Delta$ Net Assets $_{t+1}$, and Cash ${ }_{t}$ are found negatively insignificant related to the value.

Panel (II) of Table 4 reports the result of linear regression for the entire sample, for constrained and unconstrained firms, the analysis examines the effects WCM on firm valuation. The finding of this table indicates that net working capital $\left(\mathrm{NWC}_{\mathrm{t}}\right)$ is a significant variable $(p=0.011)$ at the level of 10 percent and the coefficient $(-3.308)$, what the result suggests that the decreased valuation of the investment on net working capital is primarily driven by its financing effects. Earning is found highly significant $(\mathrm{p}=0.000)$ at the level of 1 percent. We note that $\Delta$ Earning $_{\mathrm{t}}$ and $\Delta$ Earning $_{\mathrm{t}+1}$ are found to be positive insignificant Interest $_{\mathrm{t}}$ and $\Delta$ Interest $_{\mathrm{t}+1}$ are positive and negative highly significant ( $p=0.000$ and 0006, respectively) at the level of 1 percent. But $\Delta$ Interest

\begin{tabular}{|c|c|c|c|c|c|c|c|}
\hline & NWC & Earnings & Interest & Dividend & Net Assets & Cash & Firm Value \\
\hline Mean & 0.168797 & 0.09828 & 0.025672 & 0.050467 & 0.672823 & 0.043417 & 2.202728 \\
\hline Standard Deviation & 0.193869 & 0.162228 & 0.053377 & 0.121823 & 0.957064 & 0.072143 & 6.77429 \\
\hline Kurtosis & 7.169875 & 29.22469 & 25.62494 & 43.43577 & 33.06033 & 15.56588 & 57.95556 \\
\hline Skewness & 0.804614 & 4.842409 & 4.6939 & 6.142887 & 5.44095 & 3.390534 & 7.39887 \\
\hline Minimum & -0.85173 & -0.21674 & 0 & 0 & -0.4941 & 0.000204 & 0 \\
\hline Maximum & 1.375388 & 1.28728 & 0.438903 & 1.105901 & 8.379104 & 0.57354 & 69.63771 \\
\hline Count & 490 & 490 & 490 & 490 & 490 & 490 & 490 \\
\hline
\end{tabular}

Source: Author's analysis 


\begin{tabular}{|c|c|c|c|}
\hline & Constrained & Unconstrained & $\mathbf{t}$ Stat \\
\hline NWC $_{\mathrm{t}}$ & 0.155933379 & 0.195327154 & -2.11679 \\
\hline Value $_{\mathrm{t}}$ & 0.119142837 & 0.055248985 & 4.155846 \\
\hline$\Delta$ Value $_{\mathrm{t+1}}$ & 0.109021451 & -0.04085885 & 0.378595 \\
\hline$\Delta$ Earning $_{\mathrm{t}}$ & 0.000453128 & -0.000470081 & 0.169565 \\
\hline Earning $_{\mathrm{t}}$ & 0.119142837 & 0.055248985 & 4.155846 \\
\hline$\Delta$ Earning $_{\mathrm{t+1}}$ & -0.00047914 & -0.001407216 & 0.162569 \\
\hline$\Delta$ Net Asset $_{\mathrm{t}}$ & 59.19699461 & 0.034537306 & 0.695732 \\
\hline$\Delta$ Net Asset $_{\mathrm{t}+1}$ & 0.019338863 & 0.015381063 & 0.078873 \\
\hline Dividend $_{\mathrm{t}}$ & 0.06251075 & 0.025625272 & 3.171987 \\
\hline$\Delta$ Dividend $_{\mathrm{t}}$ & -0.00359938 & 0.009123568 & -1.31524 \\
\hline$\Delta$ Dividend $_{\mathrm{t}+1}$ & -0.00128685 & -0.004544662 & 0.380075 \\
\hline Cash $_{\mathrm{t}}$ & 0.048885697 & 0.032138709 & 2.421646 \\
\hline Number of Observations & 330 & 160 & 490 \\
\hline
\end{tabular}

Table 2: Descriptive statistic for constrained and unconstrained firms (1V).

\begin{tabular}{|c|c|c|c|c|}
\hline Firm Value & Coef. & Robust Std. Err & $t$ & $P>|t|$ \\
\hline $\mathrm{NWC}_{\mathrm{t}}$ & -3.30843 & 1.143076 & -2.89 & $0.006^{* * *}$ \\
\hline Earnings $_{t}$ & 19.96561 & 2.5504995 & 7.83 & $0.000^{\star * *}$ \\
\hline Earning & 8.879474 & 2.277964 & 3.9 & $0.000^{\star \star \star}$ \\
\hline Earning $_{\mathrm{t}+1}$ & 2.368625 & 7.712593 & 0.31 & 0.76 \\
\hline Interest $_{t}$ & 39.30051 & 10.92415 & 3.6 & $0.001^{* * *}$ \\
\hline Interest $_{t}$ & -2.058528 & 7.459853 & -0.028 & 0.784 \\
\hline Interest $_{t+1}$ & -27.35243 & 15.47103 & -1.77 & $0.083^{*}$ \\
\hline Dividend & 11.62538 & 4.84771 & 2.4 & $0.020^{* *}$ \\
\hline Dividend & -0.1095108 & 1.022934 & -0.11 & 0.915 \\
\hline Dividend $_{t+1}$ & -2.298465 & 1.901931 & -1.21 & 0.233 \\
\hline NetAssets $_{\mathrm{t}}$ & -0.0000214 & 0.000154 & -1.39 & 0.172 \\
\hline NetAssets $_{t+1}$ & 0.620781 & 0.4019792 & 1.54 & 0.129 \\
\hline Cash $_{\mathrm{t}}$ & 0.9360455 & 1.826663 & 0.51 & 0.611 \\
\hline FirmValue $_{t}$ & 0.4355833 & 0.0279419 & 15.59 & $0.000^{\star \star \star}$ \\
\hline R2 & & & & 0.868 \\
\hline Observations & & & & 490 \\
\hline
\end{tabular}

Significance level $=0.01^{*}$ shows $10 \%$, Significance level $=0.05^{* *}$ show $5 \%$ and Significance level $=0.001^{* \star *}$ show $1 \%$

Table 3: Panel (I) Regression for the whole sample. (V-panel 1)

\begin{tabular}{|c|c|c|c|c|}
\hline & & Robust Std. & & \\
\hline Firm Value & Coef. & Err & $\mathbf{t}$ & $\mathbf{P}>|\mathbf{t}|$ \\
\hline NWC $_{\mathrm{t}}$ & -3.30843 & 1.033178 & -3.2 & $0.011^{*}$ \\
\hline Earnings $_{\mathrm{t}}$ & 19.96561 & 3.322499 & 6.01 & $0.000^{\star * *}$ \\
\hline Earning $_{\mathrm{t}}$ & 8.879474 & 7.169362 & 1.24 & 0.247 \\
\hline Earning $_{\mathrm{t}+1}$ & 2.368625 & 3.630282 & 0.65 & 0.530 \\
\hline Interest $_{\mathrm{t}}$ & 39.30051 & 5.040711 & 7.8 & $0.000^{\star * *}$ \\
\hline Interest $_{\mathrm{t}}$ & -2.058528 & 5.965103 & -0.35 & 0.738 \\
\hline Interest $_{\mathrm{t}+1}$ & -27.35243 & 7.61651 & -3.59 & $0.006^{\star \star *}$ \\
\hline Dividend $_{\mathrm{t}}$ & 11.62538 & 4.58419 & 2.54 & $0.032^{\text {**}}$ \\
\hline Dividend $_{\mathrm{t}}$ & -.1095108 & 2.627883 & -0.04 & 0.968 \\
\hline Dividend $_{\mathrm{t}+1}$ & -2.298465 & 4.020057 & -0.57 & 0.581 \\
\hline Net Assets $_{\mathrm{t}}$ & -.0000214 & 0.0000151 & -1.42 & 0.19 \\
\hline NetAssets $_{\mathrm{t}+1}$ & 0.620781 & 0.5077516 & 1.22 & 0.253 \\
\hline Cash $_{\mathrm{t}}$ & 0.9360455 & 1.078406 & 0.87 & 0.408 \\
\hline Firm Value $_{\mathrm{t}}$ & 0.4355833 & 0.1230278 & 3.54 & $0.006^{\star * *}$ \\
\hline $\mathrm{R}^{2}$ & & & & 0.8680 \\
\hline Observations & & & & 490 \\
\hline
\end{tabular}

Significance level $=0.01$ *shows $10 \%$, Significance level $=0.05$ ** show $5 \%$ and Significance level $=0.001^{* * *}$ show $1 \%$

Table 4: Panel (II) Regression for the whole sample.

is negative insignificant. Dividend $d_{t}$ is positive significant $(p=0.032)$ at the level of 10 percent while $\Delta$ Dividend $_{t}$ and $\Delta$ Dividend $_{t+1}$ are negative insignificant. $\Delta \mathrm{Net}^{\text {Assets }} \mathrm{t}$ and $\Delta \mathrm{Net}$ Assets $_{\mathrm{t}+1}$ are found negative and positive insignificant respectively. However, in this Panel, the variable Cash $_{t}$ seems to be negative insignificant

Panel (III) of Table 5 provides the Fixed Effect Model regression result to capture the effects of WCM on firm value for both groups constrained and unconstrained firms. The variable $\mathrm{NWC}_{\mathrm{t}}$ are found negative highly significant $(\mathrm{p}=0.005)$ at the level of 1 percent. This result recommends that the negative effect of an additional investment in net working capital was driven by the need to the finance it and so bear the additional financing cost. So, precisely, we find that the investment of an additional dollar in net working capital is less in worth than invested a dollar in the cash and that increasing the level of this investment increase the valuation of firm at the reduced rate, these both effects are driven by the cost of financing associated with this investment. Earning and $\Delta$ Earning $_{\mathrm{t}}$ are positive significant $(\mathrm{p}=0.022$ and 0.057 respectively) at the level of 5 percent. $\Delta$ Earning $_{t+1}$ are found to be positive insignificant. Interest $_{t}$ seems to be positively significant $(p=0.097)$ at the level of 5 percent. $\Delta$ Interest $_{\mathrm{t}}$ and $\Delta$ Interest $_{\mathrm{t}+1}$ seem to be positively and negatively insignificant, respectively. Dividend $d_{t}$ is found to be positive significant $(\mathrm{p}=0.065)$ at the level of 5 percent and $\Delta$ Dividend $_{t+1}$ also seem to be negative significant $(\mathrm{p}=0.087)$ at the level of 5 percent while $\Delta$ Dividend are seemed to be negative insignificant in this Panel-III. $\Delta$ Net Assets is fount to positive significant $(\mathrm{p}=0.031)$ at the level of 5 percent and $\Delta \mathrm{Net}$ Assets $_{t+1}$ and Cashtare positive insignificant.

\section{The effects of financial constraint and unconstrained on the relationship of working capital and firm value}

Next, we sought to separately analysis the firms; firm size is used for the separation of the sample into two groups: financially constrained and unconstrained firms. Panel-A of Table 6 presents the linear regression results for financially unconstrained firms. Interest is highly significant at the level at 1 percent and has positive effects on the firm value while $\Delta$ Interest $_{t}$ and $\Delta$ Interest $_{t+1}$ are positive and negative insignificant related, respectively. Dividend, Dividend ${ }_{t}$ and Dividend ${ }_{t+1}$ are found positive but insignificant effects on the firm value. This can be clarified by the small sample and short time period as compared with the prior studies like Faulkender and Wang and Kieschnick et al. $\Delta$ Earning $_{\mathrm{t}+1}$ and $\Delta$ Net Assets $_{\mathrm{t}}$ are found negative as well as insignificant effects. Earning, $\Delta$ Earning $_{\mathrm{t}}$, Net Assets $_{\mathrm{t}+1}$ and Cash $_{\mathrm{t}}$ are positive but

\begin{tabular}{|c|c|c|c|c|}
\hline & & Robust Std. & & \\
\hline Firm Value & Coef. & Err & $\mathbf{t}$ & $P>|t|$ \\
\hline$N W C_{t}$ & -2.481476 & .8346739 & -2.97 & $0.005^{\star * \star}$ \\
\hline Earnings $_{\mathrm{t}}$ & 19.65994 & 8.303558 & 2.97 & $0.022^{* *}$ \\
\hline Earning $_{\mathrm{t}}$ & 8.022476 & 4.112087 & 1.95 & $0.057^{* *}$ \\
\hline Earning $^{t+1}$ & 2.50369 & 4.101393 & 0.61 & 0.544 \\
\hline Interest $_{t}$ & 55.72167 & 32.92405 & 1.52 & $0.097^{*}$ \\
\hline Interest $_{t}$ & 7.21742 & 4.738439 & -1.43 & 0.134 \\
\hline Interest $t_{t+1}$ & -30.61955 & 21.48374 & 1.89 & 0.161 \\
\hline Dividend $_{\mathrm{t}}$ & 12.09201 & 6.409502 & -0.36 & $0.065^{*}$ \\
\hline Dividend ${ }_{t}$ & -.2778336 & .7712292 & -1.75 & 0.720 \\
\hline Dividend $_{t+1}$ & -3.075042 & 1.760653 & -2.23 & $0.087^{*}$ \\
\hline NetAssets $_{t}$ & -.0000146 & $6.58 \mathrm{e}-06$ & 1.59 & $0.031^{* *}$ \\
\hline NetAssets $_{t+1}$ & .5115221 & .322214 & 0.06 & 0.119 \\
\hline Cash $_{t}$ & .1637966 & 2.757847 & 15.17 & 0.953 \\
\hline FirmValue $_{t}$ & .4308883 & .0283947 & -0.78 & $0.000^{* * *}$ \\
\hline $\mathrm{R}^{2}$ Within & & & & 0.5513 \\
\hline Observations & & & & 490 \\
\hline
\end{tabular}

Significance level $=0.01$ * shows $10 \%$, Significance level $=0.05^{* *}$ show $5 \%$ and Significance level $=0.001^{* * *}$ show $1 \%$

Table 5: Panel-III fixed effect regression for the whole sample. 


\begin{tabular}{|c|c|c|c|c|}
\hline & & Robust Std. & & \\
\hline Firm Value & Coef. & Err & $\boldsymbol{t}$ & $\boldsymbol{P}>|\boldsymbol{t}|$ \\
\hline NWC $_{\mathrm{t}}$ & -0.2651324 & .7855503 & -0.34 & 0.740 \\
\hline Earnings $_{\mathrm{t}}$ & 6.863644 & 4.327633 & 1.59 & 0.134 \\
\hline Earning $_{\mathrm{t}}$ & 3.408116 & 2.296655 & 1.48 & 0.159 \\
\hline Earning $^{+1}$ & -1.922748 & 2.137707 & -0.90 & 0.383 \\
\hline Interest $_{\mathrm{t}}$ & 7.286043 & 2.240098 & 3.25 & $0.005^{\star * *}$ \\
\hline Interest $_{\mathrm{t}}$ & 1.209193 & 1.693082 & 0.71 & 0.486 \\
\hline Interest $_{\mathrm{t}+1}$ & -1.428369 & 1.36381 & -1.05 & 0.312 \\
\hline Dividend $_{\mathrm{t}}$ & 1.256569 & 4.09333 & 0.31 & 0.763 \\
\hline Dividend $_{\mathrm{t}}$ & -0.4030608 & .2592178 & 1.55 & 0.141 \\
\hline Dividend $_{\mathrm{t}+1}$ & 1.647161 & 1.072885 & 1.54 & 0.146 \\
\hline Net Assets $_{\mathrm{t}}$ & -0.2213053 & .2443116 & -0.91 & 0.379 \\
\hline Net Assets $_{\mathrm{t}+1}$ & 0.5444417 & .2901601 & 0.19 & 0.854 \\
\hline Cash $_{\mathrm{t}}$ & 4.505245 & 2.787096 & 1.62 & 0.127 \\
\hline Firm Value $_{\mathrm{t}}$ & 0.4876055 & .0123514 & 39.48 & $0.000^{* \star *}$ \\
\hline $\mathrm{R}^{2}$ & & & & 0.4117 \\
\hline Observations $^{2}$ & & & & 160 \\
\hline
\end{tabular}

Significance level $=0.01$ * shows $10 \%$, Significance level $=0.05^{\star *}$ show $5 \%$ and Significance level $=0.001^{* * *}$ show $1 \%$

Table 6: Panel A - linear regression for unconstrained firms.

\begin{tabular}{|c|c|c|c|c|}
\hline & & Robust Std. & & \\
\hline Firm Value & Coef. & Err & $\mathbf{t}$ & $\mathbf{P >}|\mathbf{t}|$ \\
\hline NWC $_{\mathrm{t}}$ & -1.535446 & 0.7959826 & -1.93 & $0.055^{\star \star}$ \\
\hline Earnings $_{\mathrm{t}}$ & 10.01372 & 2.594821 & 3.86 & $0.000^{\star \star \star}$ \\
\hline Earning $_{\mathrm{t}}$ & 0.3926272 & 2.651772 & 0.15 & 0.882 \\
\hline Earning $^{\mathrm{t+1}}$ & 2.879242 & 2.721338 & 1.06 & 0.291 \\
\hline Interest $_{\mathrm{t}}$ & 81.86891 & 5.846737 & 14.00 & $0.000^{\star \star \star}$ \\
\hline Interest $_{\mathrm{t}}$ & -4.163426 & 7.812498 & -0.53 & 0.594 \\
\hline Interest $_{\mathrm{t}+1}$ & -52.77928 & 7.277959 & -7.25 & $0.000^{\star \star \star}$ \\
\hline Dividend $_{\mathrm{t}}$ & 13.05124 & 3.458326 & 3.77 & $0.000^{\star \star \star}$ \\
\hline Dividend $_{\mathrm{t}}$ & -0.7167096 & 2.662615 & -0.27 & 0.788 \\
\hline Dividend $_{\mathrm{t}+1}$ & -0.3751823 & 1.731096 & -0.22 & 0.829 \\
\hline NetAssets $_{\mathrm{t}}$ & $9.77 \mathrm{e}-06$ & 0.0001267 & 0.08 & 0.939 \\
\hline NetAssets $_{\mathrm{t+1}}$ & 0.5048692 & 0.2516241 & 2.01 & $0.046^{\star \star}$ \\
\hline Cash $_{\mathrm{t}}$ & 3.100206 & 1.835955 & 1.69 & $0.092^{\star}$ \\
\hline FirmValue $_{\mathrm{t}}$ & 0.4716117 & 0.0387364 & 12.17 & $0.000^{\star * \star}$ \\
\hline $\mathrm{R}^{2}$ & & & & 0.9129 \\
\hline Observations $^{2}$ & & & & 330 \\
\hline
\end{tabular}

Significance level $=0.01$ * shows $10 \%$, Significance level $=0.05^{* *}$ show $5 \%$ and Significance level $=0.001^{* * *}$ show $1 \%$

Table 7: Panel B - fixed effect regression for constrained firms.

found insignificant effects on firm value. $\mathrm{RnD}_{\mathrm{t}}, \Delta \mathrm{RnD}_{\mathrm{t}}$ and $\Delta \mathrm{RnD}_{\mathrm{t}+1}(0$, if data missing) and also expected insignificant. Net Working Capital is also negatively related and has insignificant effects the firm value. It is noted that the value of the coefficient of Cash is found higher than the coefficient of Net Working Capital, demonstrating that Cash has a greater impact on firm value. This result is similar with Autukaite and Moley, Kieschnick et al., Kieschnick et al., and Wasiuzzaman. Effects of working capital found negative so far in the context of Pakistani firms.

Panel-B of Table 7 presents the results for the financially constrained firms. The coefficient of $\mathrm{NWC}_{t}$ is negative and significant at the level of 5 percent, which is what originally expected, additional investment in the dollar in working capital, at the current level of working capital, reduce the firm value by $\$ 1.33$. We believe that this evidence helps to understand the importance of efficient working capital management. Furthermore, the results are consistent with the results of Deloof et al. that confirm that firms looking for to maintain an optimal level of working capital in order to maximize their value. The coefficient of
$\Delta$ Net Asset $_{\mathrm{t}}$ and $\Delta \mathrm{Net}^{\text {Assets }} \mathrm{t}_{\mathrm{t}+1}$ are positive and also found statistically significant at the level of 5 percent; the coefficient of Cash $h_{t}$ is positive and significant at the level of 5 percent, which means one dollar investment in cash increase the value of the firms by $\$ 3.10$. Earnings is highly significant at 1 percent with a positive coefficient, while $\Delta$ Earnings, and $\Delta$ Earnings $_{\mathrm{t}+1}$ are found to be positive but insignificant. Again, it is noted that Interest $t_{t}$ and $\Delta$ Interest $_{t+1}$ are highly statistically significant at 1 percent with positive and negative effects respectively. $\Delta$ Interest $_{t}$ is found positive but insignificant effect on valuation. Dividend is positive and highly significant at 1 percent while $\Delta$ Dividend $_{t}$ and $\Delta$ Dividend $_{t+1}$ are found to be negative as well as insignificant.

Comparison between financially constrained and unconstrained firms presents that the coefficients of variables are higher for constraint firms than the unconstrained firms. Earning, Interest $_{t}$, Interest ${ }_{t+1}$ and Dividend $_{\mathrm{t}}$ are highly significant $(\mathrm{p}=0.000)$ at the level of 1 percent for constraint firms but not for the unconstrained firms. Net assets NWCt, and Casht, are highly significant in affecting the firm value ( $p=0.046,0.055,0.092$ respectively) at the level of 5 percent for the constrained firms but insignificant for the unconstrained firms, indicates that the contribution of NWC and Cash is higher and more important for the constrained firms in contrast to unconstrained firms. The coefficient of Net assets $s_{t+1}$ is higher for constrained firms whereas the coefficient of constrained firms (3.10) of Cash $\mathrm{t}_{\mathrm{t}}$ is lower than that of unconstrained firms (4.50) and the coefficient of constrained firms $(-1.535) \mathrm{NWC}_{\mathrm{t}}$ is higher than that of the unconstrained firms $(-0.265)$. This indicates that the sensitivity of cash and net working capital is higher for the financially constrained firms. Interest is found highly significant for both ( $p=0.000$ and 0.005$)$ at the level of 1 percent but the value is higher for the constrained firms whereas, Interest $t_{t}$ is only variable turns significant for unconstrained firms but the value is higher for constrained relative to the unconstrained firms. $\mathrm{RnD}_{t}, \mathrm{RnD}_{\mathrm{t}}$ and $\mathrm{RnD}_{\mathrm{t}+1}$ remain insignificant for the both group of firms. Earning $\mathrm{t}^{\prime}$ Earning $_{t+1}$, Interest $t_{t}$ Dividend, Divident $t_{t+1}$ and Net Assets $t_{t+1}$ are insignificant for both group of firms but Earning ${ }_{t}$, Interest $t_{t}$, Dividend ${ }_{t^{\prime}}$ Divident $_{t+1}$ the valued higher for unconstrained firms except Earning ${ }_{t+1}$, and Net Assets $s_{t+1}$ valued are higher for constrained firms.

\section{Discussion}

Interestingly, the evidence of our findings is similar to the findings of Faulkender and Wang, Autukaite and Molay, Kieschnick et al., and Wasiuzzaman [3]. The investment of an extra dollar in the net working capital is less than that an extra dollar invested in the cash. However, evidence given in Fazzari and Peterson the investment in the working capital is more sensitive in financially constrained than investment in the net assets. The mean values for all variables are higher for the constrained firms except for Earning ${ }_{1}$ Earning $_{t+1}$, Dividend ${ }_{1}$ and Dividend $_{t+1}$. This is due to the unconstrained firms have better access to the capital market.

The result of regression analysis also indicates consistent evidence in Faulkender and Wang and Wasiuzzaman. Next, we analyzed the net working capital as it represents the effects of the value of a dollar invested in the net working capital the conditional on the level of current net working capital investments. We examine the entire sample as well as divide the sample into two groups financial constrained and unconstrained. The results of our study make it clear that why corporate finance emphasis on the importance of working capital management and firms too. Examining the regression Panel-I, II and III of Tables 3-5, we do observe $\mathrm{NWC}_{t}$ is highly negative significant coefficient. This result proposes that at the average level invested in the net working capital 
and its added value is reducing at a rate of \$-3.038 per extra dollar of the investment. These findings also in line with Fazzari and Petersen that marginal valuation argument of the investing in the working capital. Evidence of our study, reveals the significance for the firm's efficiently manages their net working capital well ordered as possible. The result of Panel-I, II and III of Tables 3-5 shows Earnings is significant and positively related. Further, $\Delta$ Earnings $_{t}$ is positive significant in Panel-I and II of Tables 3 and 4 but $\Delta$ Earnings $_{t+1}$ is insignificant in Panel-I, II and III of Tables 3-5 also $\Delta$ Earning $_{t+1}$ is insignificant in Panel-II of

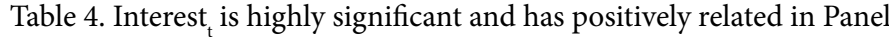
I and II and III of Tables 3-5. Although, $\Delta$ Interest $_{t+1}$ is to be negatively significant related to the firms in Panel I and II of Tables 3 and 4 but insignificant in Panel-III of Table 5 and $\Delta$ Interest $_{t}$ is found negative insignificant in all Panel of Table 5. The result of all three Panel shows that Dividend ${ }_{t}$ are significant and positively affect the firm value. While $\Delta$ Dividend $_{t+1}$ seem negative significant in Panel-III. But $\Delta$ Dividend $_{t}$ and $\Delta$ Dividend $_{t+1}$ are found to be negatively insignificant in Panel-I and II. $\Delta$ Net Assetst, is found positive significant in the result of Panel-III, while $\Delta$ Net Assets $_{t+1}$ is positive insignificant in Panel I, II and III. The

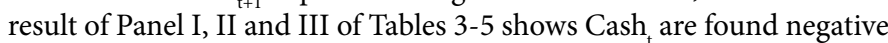
and positive insignificant related to the value, respectively.

Looking at the effects of financial constrained and unconstrained on the relationship of the working capital and valuation of firms, we examine linear regression result shown in Panel-A of Table 6 for unconstrained firms and fixed effect regression result shown in Panel-B of Table 7 for constrained firms and key results are again similar with Faulkender and Wang, the values of constrained are higher than that the values of unconstrained firms.

Looking at differences in the coefficient for constrained against unconstrained, another interesting finding emerges. Earning, Interest, Interest $_{t+1}$, and Dividend $d_{t}$ are highly significant for constraint firms but not for the unconstrained firms and also coefficients of these variables are higher for the constrained relative to the unconstrained. The average value of a dollar distribution through dividends is higher in the group of constrained firms. Firms which pay low dividends also have less cash flow than the high dividend firms. The reason behind this, firms with low dividend consists of unconstrained firms and these firms' shows the higher sensitivity for cash flow due to their access to the external markets since firms with low dividend should be effective access to the external markets than that high dividend firms.

Net assets $s_{t+1}, N^{\prime}$, and Cash $h_{t}$ are highly significant in the group of constrained firms but insignificant in the group of unconstrained firms. The coefficient of Net assets $s_{t+1}$ and $\mathrm{NWC}_{t}$ are higher for constrained firms. This indicates that the sensitivity of net working capital is higher for the financially constrained firms. These results suggest that market responds more positively to the new investments made by the constrained. Whereas the coefficient of the constrained firms for Cash is less than that of the unconstrained firms, is not consistent with the evidence of Faulkender and Wang and Shaista Wasiuzzaman, they suggest that cash reserve is more valuable to the financially constrained firms and mostly reliant on the internal funds and therefore the level of cash holding is higher than do that can be ease of the access more cash when they need it. Interest is highly significant for both groups of firms whereas, Interest is only variable turns significant for an unconstrained group of firms but the value is higher for constrained relative to the unconstrained firms. $\mathrm{RnD}_{t}, \mathrm{RnDt}$, and $\mathrm{RnD}_{\mathrm{t}+1}$ remain insignificant for the both group of firms. Earning ${ }_{t}$, Earning $g_{t+1}$, Interest $t_{t}$, Dividend $t_{t}$ Divident $_{t+1}$ and Net Assets $s_{t+1}$ are insignificant for both constrained and unconstrained firms but Earning ${ }_{t}$, Interest $t_{t}$, Dividend ${ }_{t}$, Divident ${ }_{t+1}$ the valued higher for unconstrained firms except Earning ${ }_{t+1}$, and Net Assets $_{t+1}$ valued are higher for constrained firms (Appendices 1 and 2).

\section{Conclusion}

Management of working capital is essential to the firm value. There are no studies published to date available on the effects of working capital on the valuation of the firm, especially in the context of Pakistan; even though the fact that textbooks of corporate finance discuss this subject as if it is crucial to the valuation of the firm. Consequently, in this study, we aim to determine how working capital affects the firm valuation and provide evidence on the basis of our findings for Pakistani Firms.

Further, and just importantly, in addition, we also determine the effects of financially constrained and unconstrained on the association of working capital management and the firm value. Using a sample 49 Pakistani firms listed on Karachi Stock Exchange for a time period of 2004 to 2016 and a total 490 observations. The evidence of regression analysis exhibit how vital is to the management of working capital efficiently and this is truly associated with financially constrained firms as it affects the firm value while for the unconstrained firms it is not true that better management of working capital is crucial for the firm value. This is confirming that financially constrained firms seek to hold the optimal level of the working capital for maximizing their firm value.

The contribution of this study to the limited but growing literature on the working capital management, an area that has not been given much attention it needs, especially in the context of Pakistani firms. The results of this study would be helpful for the managers and highlight the importance of efficient working capital management, not only managers but also helpful for the investors in evaluating the management of working capital as it may be able to give some valuable indication about the financial wellbeing, in addition, to choose the best investment options.

We hope that this study may contribute to the development of research in future on the theme of working capital management. Therefore, we propose the improvement for studies in future by the considering similar study could be carried on the impact of the working capital policies on the firm valuation. Relationship and impact of the working capital should also examine with capital expenditure, risk management, and shareholder wealth. Furthermore, the future researcher may consider other variables such liquidity, capital structure policy, dividend policy and earnings which may provide a more clear picture of the relationship of net working capital and its effects on firm value is needed especially given the limited literature on this issue.

\section{References}

1. Fama EF, French KR (1998) Taxes, financing decisions, and firm value. Journa of Finance, pp: 819-843.

2. Pinkowitz L, Stulz R, Williamson R (2006) Does the contribution of corporate cash holdings and dividends to firm value depend on governance? A Crosscountry analysis. The Journal of Finance LXI: 2725-2751.

3. Wasiuzzaman S (2015) Working capital and firm value in an emerging market International Journal of Managerial Finance 11: 60-79.

4. Rehman A, Nasr M (2007) Working capital management and profitability-case of Pakistani firms. International. Review of Business Research Papers 3: 279 300 .

5. Charitou MS, Elfan M, Lois P (2010) The effect of working capital management on firm's profitability: Empirical Evidence from an Emerging Market. Journal of Business and Economic Research 14: 111-118.

6. Afza T, Nazir MS (2007) Is it Better to be aggressive or conservative in managing working capital? Paper presented at Singapore Economic Review Conference (SERC). 
7. Lazaridis I, Tryfonidis D (2006) Relationship between working capital management and profitability of listed companies in the Athens stock exchange. Journal of Financial Management and Analysis 19: 26-25.

8. Falope OI, Ajilore OT (2009) Working capital management and corporate profitability: Evidence from panel data analysis of selected quoted companies in Nigeria. Research Journal of Business Management 3: 73-84

9. Mathuva DM (2010) The influence of working capital management components on corporate profitability: A survey on Kenyan Listed Firms. Research Journal of Business Management 4: 1-11.

10. Mansoori E, Muhammad E (2012) The effect of working capital management on firm's profitability: evidence from Singapore. Interdisciplinary Journal of Contemporary Research in Business 4: 472-486.

11. Arnold G (1998) Corporate Financial Management. (1st edn.), Pitman Publishing, London 4: 543.

12. Weston JF, Brigham EF (1977) Essentials of managerial finance Illinois. The Dryden Press, Weston.

13. Shin HH, Soenen L (1998) Efficiency of working capital management and corporate profitability. Financial Practice and Education 8: 37-45.

14. Pandey IM (2007) Financial Management. (9th Edn), Vikas Publishers, New Delhi.

15. Paramasivan C, Subramanian T (2009) Financial management. New Age International, pp: 283

16. Brigham EF, Houston JF (2002) Fundamental of financial management. (13th edn.), Ohio: Southwest Division of Thompson Learning Incorporation.

17. Eljelly AMA (2004) Liquidity-Profitability Tradeoff: An Empirical Investigation in an Emerging Market, International Journal of Commerce and Management 14: 48-61.

18. Gill A, Biger N, Mathur N (2010) The Relationship between working capital management and profitability: Evidence from the United States. Business and Economics Journal 10: 1-9.

19. Vida M, Tabari SHA, Mosayebi R (2011) The Relationship between Working Capital Management and Profitability of the Companies. International Research Journal of Finance and Economics 76: 158-166.

20. Alipour M (2011) Working capital management and corporate profitability: Evidence from Iran. World Applied Sciences Journal 12: 1093-1099.

21. Al- Debi'e MM (2011) Working capital management and profitability of industria firms in Jordan. European Journal of Economics, Finance and Administrative Sciences, pp: 1450-2275

22. Rahman MM (2011) Working capital management and profitability: A study on Textiles Industry. ASA University Review 5: 115-132.

23. Usama M (2012) Working capital management and its effect on firm's profitability and liquidity: In other foods sector of (KSE) Karachi Stock Exchange. Arabian Journal of Business and Management Review.

24. Akbar FA, Arani ZG (2012) The Assessment of the effect of working capita management on the profitability of pharmaceutical companies of Tehran stock exchange. American Journal of Scientific Research, pp: 121-129.

25. Onwumere JUJ, Ibe IG, Ugbam OC (2012) The impact of working capital management on profitability of Nigerian Firms: A preliminary Investigation. European Journal of Business and Management 4: 192-201.

26. Pouraghajan A, Emamgholipourarchi M (2012) Impact of working capita management on profitability and market evaluation: evidence from Tehran stock exchange. International Journal of Business and Social Science 3: 311 318.

27. Ali A, Ali SA (2012) Working capital management: Is it really affects the profitability? Evidence from Pakistan. Global Journal of Management and Business Research 12: 2249-4588.

28. Sarbapriya R (2012) Evaluating the impact of working capital management components on corporate profitability: Evidence from Indian Manufacturing Firms. International Journal of Economic Practices and Theories 2: 127-136.

29. Uremadu SO, Egbide B, Enyi PE (2012) Working capital management, liquidity and corporate profitability among quoted firms in Nigeria evidence from productive sector. International Journal of academic Research in Accounting, Finance and Management Sciences 2: 80-97.
30. Ding S, Guariglia A (2013) Investment and financing constraints in China: Does working capital management make a difference? Journal of Banking \& Finance 37: 1490-1507.

31. Zubair A, Muhammad YG (2013) Impact of working capital management on profitability: A case of the Pakistan Cement Industry. Interdisciplinary Journal of Contemporary Research in Business 5: 384-390.

32. Oladipupo AO, Okafor CA (2013) Relative contribution of working capital management to Corporate profitability and Dividend payout ratio: Evidence from Nigeria. International Journal of Business and Finance Management Research 1: 11-20.

33. Reddy RM (2011) Impact of working capital management on firms profitability. Global Journal of Finance and Management 3: 151-158.

34. Ngwenya S (2012) The relationship between working capital management and profitability of companies listed on the Johannesburg Stock Exchange. Journal of Modern Accounting and Auditing 8: 1204-1213.

35. Barine MN (2012) Working capital management efficiency and corporate profitability: Evidences from quoted firms in Nigeria. Journal of Applied Banking and Finance 2: 215-237.

36. Owolabi SA, Alu CN (2012) Effective working capital management and profitability: A study of selected quoted manufacturing companies in Nigeria. Economic and Finance Review 6: 55-67.

37. Zahra M, Jari A (2012) The relationship between working capital management and firm performance: evidence from Iran. International Journal of Humanities and Social Science 2: 141-146.

38. Okwo IM, Ugwunta DO, Agu SU (2012) An examination of the factors that determine the profitability of Nigerian beer brewery firms. Asian Economic and Financial Review 2: 741-750

39. Ghaziani B, Zadeh (2012) Investigation of the Relationship between components of working capital management with market valuation and profitability in firms listed in Tehran Stock Exchange. Trends in Social Science, Science Road Publishing Corporation, TSS 1: 55-63.

40. Mehra $P$ (2013) Effect of working capital management on the profitability of the Indian Pharmaceutical sector. International Journal of Enhanced Research in Management and Computer Applications 2: 2219-7471.

41. Hamid B, Waqar A (2013) Does efficient working capital management enhance profitability of Pakistani Firms? Management and Administrative Sciences review 2: 715-720.

42. Alavinasab SM, Davoudi E (2013) Studying the relationship between working capital management and profitability of listed companies in Tehran Stock Exchange. Business Management Dynamics 2: 01-08.

43. Dittmar A, Mahrt-Smith J (2007) Corporate governance and the value of cash holdings. Journal of Financial Economics pp: 1-45.

44. Kalcheva I, Lins KV (2007) International evidence on cash holdings and expected managerial agency problems. The Review of Financial Studies 20 1088-1112.

45. Luo Q, Hachiya T (2005) Corporate governance, cash holdings, and firm value: Evidence from Japan. Review of Pacific Basin Financial Markets and Policies 8: 613-636.

46. Lee KW, Lee CF (2009) Cash holdings, corporate governance structure and firm valuation. Review of Pacific Basin Financial Markets and Policies 12: 475508.

47. Harford J (1999) Corporate cash reserves and acquisitions. Journal of Finance 54: 1969-1997.

48. Opler T, Pinkowitz L, Stulz R, Williamson R (1999) The determinants and implications of cash holdings. Journal of Financial Economics 52: 3-46.

49. Kieschnick R, LaPlante M, Moussawi R (2008) Working capital management agency costs, and firm value. Financial Management Association Annual Meeting, Financial Management Association, Grapevine, TX.

50. Luo M (2009) Cash conversion cycle, firm performance and stock value.

51. Mohamad NEA, Saad NM (2010) Working capital management: The effect of market valuation and profitability in Malaysia. International Journal of Business and Management 5: 140-147.

52. Parvaneh MM, Chashmi AN (2014) Examining the impact of financing methods 
Citation: Shah B, Arif M (2018) Working Capital Efficiency and Firm Value: Evidence form Pakistani Firms. J Bus Fin Aff 7: 320. doi: 10.4172/21670234.1000320

and working capital management on value of the listed companies in Tehran stock exchange. Tehran: Advances in Environmental Biology

53. Almeida H, Campello M, Weisbach MS (2004) The cash flow sensitivity of cash. Journal of Finance 59: 1777-1804

54. Moyen N (2004) Investment-cash flow sensitivities: Constrained versus unconstrained firms. The Journal of Finance, pp: 1-48.

55. de Almedia JR, William E (2014) Access to finance, working capital management and company value: Evidence from Brazilian companies listed on BM\&FBOVESPA. Journal of Business Research 67: 924-934.
56. Denis DJ, Sibilkov V (2010) Financial constraints, investment, and the value of cash holdings. The Review of Financial Studies 23: 247-269.

57. Kieschnick R, Moussawi R, LaPlante M (2006) Corporate working capital management: Determinants and Consequences

58. Chiou J, Cheng L, Wu H (2006) The determinants of working capital management. The Journal of American Academy of Business, Cambridge 10: 149-155.

59. Kieschnick R, LaPlante M, Moussawi R (2009) Working capital management access to financing, and firm value. 